\title{
HUBUNGAN ANTARA KETERLIBATAN KERJA DENGAN TURNOVER INTENTION PADA KARYAWAN PT. GARDA TRIMITRA UTAMA, JAKARTA
}

\author{
Roni Faslah*
}

\begin{abstract}
The purpose of this research is to get a valid and reliable data or fact, to know the correlations between job involvement with turnover intention to employee PT. Garda Trimitra Utama, Jakarta. The analysis test by finding regression equation, that is $\hat{Y}=75,304-0,238 X$. For regression significance test and the result is, $F_{\text {count }}$ $(5,94)>F_{\text {table }}(4,03)$. Showing that, it has significance regression. While regression linearity test, $F_{\text {count }}(1,54)<F_{\text {table }}=(1.96)$, showing that regression is linear. The result of product moment of correlations coefficient test, is $r_{x y}=-0,231$ continued by using correlations coefficient significance test with t-test. Counting result is, $t_{\text {count }}(-1,73)<-t_{\text {table }}(-1,67)$. It means that there are significance and negative correlations between job involment with turnover intention.Beside that, the result of determination coefficient test is 5,34\%, it means that turnover intention to employee variable determined by 5,34\% job involvement variable. The conclusion of the research have shown that there is a negative correlations between job involvement with turnover intention to employee.
\end{abstract}

Keywords: correlation, job involvement, trunover intention, survey, regression.

\section{PENDAHULUAN}

Karyawan merupakan faktor produksi penting bagi perusahaan, disamping faktor lainnya seperti bahan produksi, modal, pasar, ataupun penggunaan mesin-mesin teknologi baru. Hal ini dikarenakan manusia adalah sebagai perencana, pelaku dan penentu terwujudnya kebutuhan dan tujuan perusahaan. Dengan demikian perusahaan memerlukan karyawan yang terampil, cakap, dan memiliki semangat kerja yang tinggi dalam menyelesaikan

Roni Faslah. Dosen Fakultas Ekonomi Universitas Negeri Jakarta. pekerjaan yang sesuai dengan bidang usaha perusahaan.

Perusahaan dituntut untuk memperoleh, mengembangkan dan mempertahankan sumber daya manusia yang berkualitas. Setiap perusahaan menginginkan karyawannya memiliki kemampuan produktivitas yang tinggi dalam bekerja. Hal ini merupakan keinginan yang ideal jika perusahaan tersebut diisi dengan karyawan yang produktif.

Keluar dari tempat kerja atau berpindah kerja (Turnover) merupakan salah satu pilihan jika seorang karyawan sudah merasa tidak cocok atau tidak sesuai lagi dengan apa yang ingin diharapkan di 
tempat kerjanya. Turnover sebagai akibat dari keinginan berpindah (turnover intention) bagi karyawan diplih karena berharap ingin memperbaiki keadaan dari sisi psikologis maupun karir masa depan yang lebih baik, namun dari sisi perusahaan pergantian karyawan (Turnover) yang tinggi akan menimbulkan dampak negatif, seperti menciptakan ketidakstabilan terhadap kondisi tenaga kerja dan peningkatan biaya sumber daya manusia. Hal tersebut menjadikan organisasi dalam perusahaan tidak efektif karena kehilangan karyawan yang berpengalaman dan perlu melatih kembali karyawan baru.

Banyak faktor yang dapat mempengaruhi keinginan berpindah dari perusahaan (turnover intention) pada diri karyawan, diantaranya adalah komitmen organisasi, ketidakamanan kerja, kinerja karyawan, stres kerja, pengembangan karir, kepuasan kerja dan keterlibatan karyawan yang rendah.

Faktor keterlibatan kerja, merupakan identifikasi seseorang secara psikologis terhadap pekerjaannya, berpartisipasi aktif dan pekerjaan dianggap sebagai bagian yang penting dalam kehidupan individu, namun banyak masalah yang dihadapi oleh perusahaan seperti adanya keterlibatan kerja yang rendah pada diri karyawan sehingga dapat mengakibatkan tingginya keinginan berpindah (turnover intention) pada karyawan. Banyak perusahaan yang tidak menyadari pentingnya memberikan kesempatan karyawan untuk terlibat dalam organi- sasi, misalnya seperti keterlibatan dalam pengambilan keputusan, hal ini dapat memicu rasa motivasi yang rendah karena merasa tidak ada kesempatan untuk berkembang, sehingga tidak dapat membantu memuaskan kebutuhan seorang karyawan akan tanggung jawab, prestasi, pengakuan, dan peningkatan harga diri.

\section{LANDASAN TEORI \\ Turnover Intention}

Pergantian karyawan atau keluar masuknya karyawan dari organisasi merupakan suatu fenomena yang penting. Sebelum karyawan melakukan tindakan turnover, mereka mempunyai keinginan atau intensi untuk keluar dari perusahaan. Turnover intention (keinginan berpindah) dapat mengarah langsung pada turnover nyata. Good et.al menyatakan bahwa turnover intention adalah intensi seseorang untuk melakukan pemisahan aktual (turnover) dari suatu organisasi (Sunjoyo, 2002).

Umi manyatakan bahwa Turnover intention refers to the intention of an employee looking for alternative work in other places and has not been implemented in a actual behavior (Umi N, 552:2007). Pernyataan ini menunjukkan bahwa Keinginan berpindah mengacu pada maksud seorang karyawan mencari tempat pekerjaan alternatif lainnya dan belum diimplementasikan dalam perilaku aktual.

Anggaryono menyatakan bahwa turnover intention adalah tingkat kekuatan niat karyawan untuk keluar 
dari perusahaan atas prakarsa karyawan itu sendiri baik disertai imbalan dari perusahaan atau tidak (Joko Nugroho, 2008).

Wayne et.al dalam Fransiskus (2006) menyatakan bahwa, Intensi turnover merupakan keinginan untuk keluar dari tempat kerja sekarang dan mencari alternatif pekerjaan yang lebih baik di tempat lain.

Dengan demikian dapat dikatakan bahwa turnover intention atau keinginan berpindah merupakan suatu niat dari hasil berpikir karyawan untuk keluar atau meninggalkan perusahaannya untuk mencari alternatif pekerjaan yang lebih baik. Jadi faktor penentu adanya niat pindah dari perusahaan atau turnover intention antara lain kurangnya kepuasan kerja, kurangnya ketertarikan pada pekerjaan yang sekarang dan ketertarikan yang diharapkan pada alternatif pekerjaan.

Heneman et. all (2006) menyatakan bahwa The employee's intention to quit depend on three general factors: the perceived desirability of leaving, the perceived ease of leaving, and alternatives available to the employee. Keinginan untuk keluar karyawan tergantung pada tiga faktor umum: mengamati sifat menginginkan meninggalkan, mengamati mudahnya meninggalkan, dan penggunaan alternatif untuk karyawan.

Dapat dianalisa bahwa keinginan karyawan untuk keluar dari perusahaan dengan mengamati atau melihat faktor sifat keinginannya seperti pengaruh ketidakpuasan, konflik kerja-keluarga, dan alasan pribadi lainnya, apakah mudah menemukan pekerjaan baru setelah meninggalkan perusahaan; dan pekerjaaan alternatif lainnya di tempat lain jika karyawan sudah meninggalkan perusahaan.

Menurut Abelson dalam Yayuk (2006) menyatakan bahwa sebagian besar karyawan yang meninggalkan organisasi dan belum diwujudkan dalam tindakan pasti meninggalkan organisasi karena alasan sukarela dapat dikategorikan atas perpindahan kerja.

Ada beberapa alasan positif dan negatif karyawan terhadap turnover intention (keinginan berpindah). Hoonakker et. al dalam Rochmi (2006) menemukan alasan positif dan negatif karyawan terhadap turnover intention, yaitu sebagai berikut:

1. Alasan positif: Memperoleh gaji lebih tinggi dan perencanaan kompensasi yang lebih baik, Keinginan memperoleh kesempatan untuk belajar sesuatu yang baru, Memperoleh keahlian yang berbeda dari sebelumnya dan mengembangkan karir.

2. Alasan negatif: Reward, perencanaan karir, dan kesempatan berkembang kurang mendapat perhatian dari perusahaan, dan Dihubungkan dengan pekerjaaan dan faktor organisasi, berupa: jam kerja yang lebih panjang, kurang tantangan, konflik kerja dan keluarga, manajemen yang tidak efektif, pelatihan, adanya diskriminasi dan perasaan tidak cocok pada tempat kerja. 
Roni Faslah : Hubungan Antara Keterlibatan Kerja Dengan Turnover Intention Pada Karyawan PT. Garda Trimitra Utama, Jakarta

Keterlibatan Kerja

Robbins dan Coulter (2007) mengatakan bahwa keterlibatan kerja adalah tingkat pengidentifikasian psikologis karyawan dengan pekerjaannya, secara aktif berpartisipasi dalam pekerjaannya, dan menganggap kinerjanya di pekerjaannya adalah penting untuk kebaikan dirinya sendiri.

Allport dalam Charlie L Reeve, et.al (2001) mengemukakan bahwa keterlibatan kerja adalah degree to which an employee is participating in his/her job and meeting such needs as prestige and autonomy. Keterlibatan kerja derajat sampai dimana karyawan yang berpartisipasi dalam pekerjaannya dan memenuhi seperti kebutuhan-kebutuhan gengsi dan otonomi.

Dapat dinyatakan bahwa aktif berpartisipasi dalam pekerjaan dapat menunjukkan seorang pekerja terlibat dalam pekerjaan. Aktif partisipasi adalah perhatian seseorang terhadap sesuatu. Menurut Pachen menyatakan bahwa ciri-ciri individu yang memiliki keterlibatan kerja yang rendah adalah individu yang memandang pekerjaan sebagai bagian yang tidak penting dalam hidupnya, memiliki rasa kurang bangga terhadap perusahaan, dan kurang berpartisipasi terhadap pekerjaannya.

Keterlibatan kerja merupakan suatu ukuran sampai dimana karyawan dapat berpartisipasi dalam pekerjaannya secara psikologis dan menganggap pekerjaannya dan kinerjanya penting. Robbins dan Coulter (2007) menyatakan bahwa karyawan dengan tingkat keterlibatan kerja yang tinggi dengan kuat mengenali dan benar-benar memerhatikan jenis pekerjaan yang mereka lakukan, tingkat yang tinggi telah ditemukan terkait dengan tingkat absensi yang lebih sedikit dan tingkat pengunduran diri karyawan yang lebih rendah. Dipertegas oleh G. J. Blau dalam Robbins (2003) yang menyatakan bahwa "Tingkat keterlibatan kerja yang tinggi telah ditemukan berkaitan dengan kemangkiran yang lebih rendah dan tingkat permohonan berhenti yang lebih rendah".

Hal ini dapat disimpulkan bahwa karyawan yang mempunyai keterlibatan kerja yang tinggi akan benar-benar serius menangani jenis pekerjaannya dengan demikian dapat mengurangi absensinya, dan dari tingkat pengunduran diri / tingkat permohonan diri karyawan yang rendah berarti sedikit sekali karyawan yang mempunyai keinginan berpindah (turnover intention).

Lodahl and Kejner's yang menyatakan beberapa definisi dari keterlibatan kerja, yaitu:

(a) Job Involvement is the degree to which a person is identified psychologically with his work, or the importance of work in his total selfimage; (b) the internalization of values about the goodness of work or the importance of work in the worth of the person and perhaps it thus measures the ease with which the person can be further socialized into an organization;(c) the degree to which a person's work performance affects his self-esteem (Charlie L. Reeve: 2001). 
Pernyataan tersebut mengindikasikan bahwa: (a) keterlibatan kerja adalah derajat dimana seseorang mengidentifikasi secara psikologis terhadap pekerjaannya, atau pentingnya pekerjaan tersebut terhadap keseluruhan citra diri; (b) internalisasi nilai-nilai mengenai kebaikan bekerja atau pentingnya bekerja dalam hal penghargaan atas diri sendiri yang nantinya akan menentukan tingkat kenyamanan seseorang dalam bersosialisasi di suatu organisasi; (c) derajat dimana kinerja seseorang mempengaruhi self esteem (harga dirinya).

Menurut Eby, et al. dalam Pare dan Tremblay (2007) menyatakan pendapat bahwa Employee discretion and influence through task involvement fosters a greater sense of support, trust, and intrinsic motivation and provides positive work attitudes.

Keterlibatan kerja pada karyawan dapat menumbuhkan tingkat yang lebih tinggi dari dukungan, kepercayaan, dan motivasi intrinsik, memberikan sikap kerja yang positif, solidaritas yang tinggi pada perusahaan dan keadaan emosi positif dari individu sehingga terhubung dengan identitas yang mereka rasakan tinggi, merasakan pekerjaan sebagai kepentingan dan tujuan hidup.

Hasil penelitian Sherman dalam Udo, et al. (1997) menyatakan bahwa Job involvement has also been found to be negatively related to turnover intentions, hasil penelitian ini menunjukkan bahwa keterlibatan kerja berhubungan negatif dengan keinginan berpindah.

\section{METODOLOGI PENELITIAN}

Penelitian ini bertujuan untuk mengetahui hubungan antara Keterlibatan Kerja dengan Turnover Intention. Metode penelitian yang digunakan adalah metode survey dengan pendekatan korelasional. Populasi penelitian ini adalah seluruh karyawan PT. Garda Trimitra Utama, sebanyak 550 orang karyawan yang ditempatkan di seluruh Indonesia, dan populasi terjangkaunya adalah seluruh karyawan yang dipekerjakan di PT. Sucofindo Pasar Minggu yang berjumlah 63 orang. Sampel diambil sebanyak 55 orang karyawan dengan taraf perhitungan kesalahan sebanyak $5 \%$. Teknik pengambilan sampel menggunakan teknik acak sederhana. Teknik analisis data dilakukan dengan uji regresi dan korelasi.

\section{HASIL PENELITIAN}

Hasil reliabilitas instrumen variabel $X$ (keterlibatan kerja) sebesar 0,85 variabel $Y$ (Turnover intention) sebesar 0,97. Uji persyaratan analisis yang dilakukan adalah dengan mencari persamaan regresi yang didapat adalah $\hat{Y}=75,304-0,238 X$.. Pengujian hipotesis dengan uji keberartian regresi menghasilkan $F_{\text {hitung }}(5,94)>F_{\text {tabel }}(4,03)$, yang berarti persamaan regresi tersebut signifikan. Uji kelinieran regresi menghasilkan $\mathrm{F}_{\text {hitung }}=1,54$ dan $\mathrm{F}_{\text {tabel }}$ $=1,96$ sehingga $F_{\text {hitung }}<F_{\text {tabel }}$ maka dapat disimpulkan bahwa model persamaan regresi adalah linier. 
Uji koefisien korelasi product moment menghasilkan $r_{\text {hitung }}=-0,231$. Selanjutnya dilakukan uji keberartian koefisien korelasi dengan menggunakan uji-t, menghasilkan $t_{\text {hitung }}(-1,73)<-t_{\text {tabel }}(-1,67)$.

Hasil penelitian tersebut menyimpulkan bahwa terdapat hubungan negatif antara keterlibatan kerja dengan Turnover Intention. Dengan uji koefisien determinasi atau penentu diperoleh hasil 5,34\% variabel Turnover intention ( $Y$ ) ditentukan oleh keterlibatan kerja (X)

\section{KESIMPULAN}

Hasil penelitian menunjukkan bahwa terdapat hubungan yang negatif antara keterlibatan kerja dengan Turnover Intention (keinginan berpindah) pada karyawan PT. Garda Trimitra Utama, Jakarta. Hubungan antara keterlibatan kerja dengan Turnover Intention adalah sebesar 0,231 . Untuk hasil perhitungan koefisien determinasi didapat hasil sebesar 5,34\% variasi turnover intention pada karyawan. Sehingga dapat disimpulkan bahwa terdapat hubungan yang negatif dan signifikan keterlibatan kerja dengan Turnover Intention (keinginan berpindah) pada karyawan PT. Garda Trimitra Utama Jakarta.

\section{DAFTAR PUSTAKA}

Charlie L Reeve, Carlla S Smith, 2001. Refining Lodahl and Kejner's job involvement scale with a convergent evidence approach: Applying multiple methods to multiple samples. Organizational Research Methods. Thousand Oaks: Apr . Vol. 4.

Ferry Novliadi. 2007. Intensi Turnover Karyawan Ditinjau Dari Budaya Perusahaan Dan Kepuasan Kerja. Medan: Fakultas Kedokteraan Universitas Sumatra Utara,

Rochmi Widayanti, 2004. Memahami Proses Pergantian Karyawan (Employee Turnover) dan Pemilihan Model Konseptual, Jurnal Javanisi, Vol. 7 No. 2.

Stephen P. Robbins, Mary Coulter. 2007. Manajemen. Jakarta:PT. Indeks.

Sunjoyo, 2002. Pengaruh Kepuasan Gaji, Konflik Peran, Ambiguitas Peran, Kepuasan Kerja, dan Komitmen Organisasional terhadap Turnover Intention, Thesis. Yogyakarta: Universitas Gajah Mada.

Tresvil G. Pack et.al, 2007. Prediction of Turnover Intentions among employed adults with multiple sclerosis, Jurnal of Rehabilitation,

Umi Narimawati, 2007. The Influence of Work Satisfaction, Organizational Commitment and Turnover Intention Towards the Performance of Lecturers at West Java's Private Higher Education Institution. Journal Of Applied Sciences Research.

Yayuk Ngeti R., 2006. "Pengaruh Kepuasan Gaji Terhadap Intensi Keluar, Kepuasan Kerja dan Komitmen Afective Sebagai Moderating Variabel', Jurnal Ekonomi Arthavidya. 